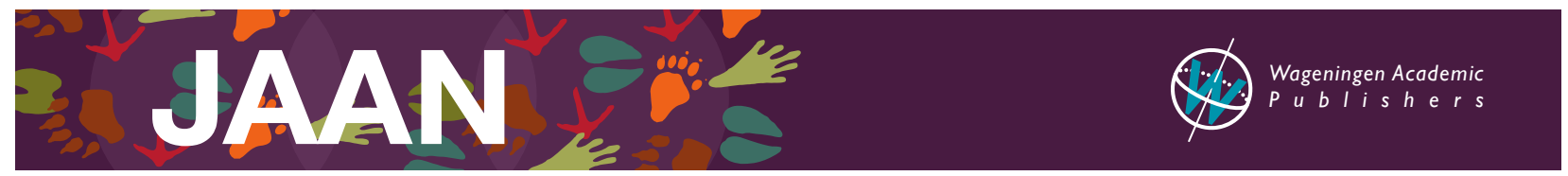

\title{
Comparison of medium chain organic acids with zinc oxide and benzoic acid; effect on growth performance of pigs
}

\author{
N. Portocarero \\ Feed, Food E Future, Brookside, Brecon Road, Hay-on-Wye, HR3 5DY, United Kingdom; np@feedfoodfuture.com
}

Received: 8 September 2021 / Accepted: 1 February 2022

(c) 2022 N. Portocarero

RESEARCH ARTICLE

PIGS

\begin{abstract}
Medium chain organic acids (MCOA) show strong and specific antimicrobial activity and may be useful as part of an antibiotic reduction strategy. Two trials were conducted to evaluate the effect of MCOA on growth performance of pigs in comparison with benzoic acid (BA) and $\mathrm{ZnO}(\mathrm{ZnO})$. Each used 240 pigs in a randomised complete block design with six treatments in eight replicate pens. Trial 1 tested a blend of C6:0, C8:0, C10:0 and C12:0 for $56 \mathrm{~d}$ post-weaning. Treatments were (1) control basal diet (BD), (2) $\mathrm{BD}+\mathrm{ZnO}$ (3) $\mathrm{BD}+\mathrm{ZnO}+\mathrm{BA}$, (4) $\mathrm{BD}+\mathrm{MCOA}$ (5) $\mathrm{BD}+\mathrm{MCOA}+\mathrm{ZnO}$, (6) $\mathrm{BD}+\mathrm{MCOA}+\mathrm{BA}$. Pigs receiving $\mathrm{MCOA}+\mathrm{BA}$ showed higher average daily liveweight gain in the grower period $(849 \mathrm{~g} / \mathrm{d})$ than pigs receiving the control diet $(773 \mathrm{~g} / \mathrm{d})$ or the $\mathrm{ZnO}$ treatment $(779 \mathrm{~g} / \mathrm{d}$; $P=0.040)$, grew $7 \%$ more efficiently $(P=0.008)$ and were $3.02 \mathrm{~kg}$ heavier at $56 \mathrm{~d}$ than control pigs. Trial 2 tested the MCOA blend at two inclusion levels in comparison with C6:0/C12:0 (50/50) and C6:0/C12 monolaurin (C12M; $50 / 50$ ), for $28 \mathrm{~d}$ post-weaning. Treatments were (1) control basal diet, (2) BD+ZnO (3) BD+1,500 mg/kg MCOA (4) $\mathrm{BD}+750 \mathrm{mg} / \mathrm{kg}$ MCOA (5) BD+C6/C12 (total 3,000 mg/kg), (6) BD + C6/C12M (total 3,000 mg/kg). Pigs receiving $750 \mathrm{mg} / \mathrm{kg}$ MCOA grew more slowly than those receiving C6/C12M or $\mathrm{ZnO}(P<0.05)$ to d 21. Pigs fed $\mathrm{ZnO}$ were $1.61 \mathrm{~kg}$ heavier than these pigs $(P<0.05)$, while those fed $\mathrm{C} 6 / \mathrm{C} 12 \mathrm{M}$ were $1.29 \mathrm{~kg}$ heavier $(P<0.05)$ at $\mathrm{d} 21$. During 0-14 d pigs fed $\mathrm{ZnO}$ showed the best feed conversion ratio (FCR), but at 15-28 $\mathrm{d}$ the improvement was no longer seen. Both the $\mathrm{C} 6 / \mathrm{C} 12$ and the $\mathrm{C} 6 / \mathrm{C} 12 \mathrm{M}$ treatments appeared to improve $\mathrm{FCR}$ during this second phase $(P<0.01)$. The results suggested that supplementation with a combination of MCOA and BA may be a promising strategy to improve growth performance while replacing $\mathrm{ZnO}$ and reducing antibiotic dependence.
\end{abstract}

Keywords: antimicrobial resistance, antibiotic reduction strategy

\section{Introduction}

There is continuing pressure to reduce the use of antibiotics in pig production. Despite progress towards reductions in many countries, antibiotics are still commonly used routinely, both prophylactically and to treat infection on farm. The highest priority critically important antimicrobials as classified by the World Health Organization are quinolones, third and higher generation cephalosporins, macrolides and ketolides, glycopeptides and polymyxins. Accurate assessment of use at farm level is difficult because of differences in reporting methods. Thus, large variations in use exists between different countries (Lekagul et al., 2019), whereby aminopenicillins accounted for $30-40 \%$ of total antibiotic use in studies from Sweden, Germany and Canada, while tetracyclines were the most commonly used in Denmark, Japan, Netherlands, Australia, Spain, France and Germany. The population correction unit (PCU), an index used by the European Medicines Agency, is calculated by dividing the active ingredient weight (in $\mathrm{mg}$ ) of all antibiotic products sold in the country by the standardised average weight (in $\mathrm{kg}$ ) of all animals at time of treatment multiplied by the number of animals (based on national statistics; Veterinary Medicines Directorate, 
2016). In the United Kingdom, antibiotic use in 2019 was similar to use in 2018 at $110 \mathrm{mg} / \mathrm{PCU}$, having fallen $60 \%$ in the three years prior (AHDB, 2019), while the use of critically important antibiotics decreased from $0.06 \mathrm{mg} /$ PCU in 2018 to at $0.04 \mathrm{mg} / \mathrm{PCU}$ in 2019. A figure of $110 \mathrm{mg} /$ PCU indicated that $110 \mathrm{mg}$ of antibiotic active ingredient was used for every kg of bodyweight at time of treatment.

Regulation EU 2019/4, which will come into force on January 29th 2022 (European Commission, 2019), will prohibit the prophylactic use of antibiotics in the European Union, except for very exceptional cases and to treat individual animals rather than groups. In parallel, there is an urgency to remove pharmacological levels of zinc oxide $(\mathrm{ZnO})$ from piglet starter feeds to meet legislation in place due to environmental reasons and concerns of cross-resistance. Zinc oxide is used routinely to prevent intestinal infection of young animals at weaning, although its mode of action has not been clearly defined. However, it has been shown to alter the enterobacterial population in the ileum of piglets (Starke et al., 2014; Vahjen et al., 2011), and it has been proposed that the influence on gastrointestinal microbiota may be through suppression of Gram-positive commensal microorganisms rather than through suppression of Gram-negative organisms (Hojberg et al., 2005) and may participate in the stabilisation of the epithelial cell membrane (Srivastava et al., 1995). Zinc oxide was estimated to be used in 70-90\% of weaned pig rations in 2017 (Driver, 2017) although it can be expected that this figure has since reduced in response to pending legislation. The proposed removal of $\mathrm{ZnO}$ leads to further concerns of a future rise in antibiotic use. Despite the progress towards reductions in the United Kingdom, antibiotics are still commonly used in the post-weaning period; both in medicated starter feeds and to treat infection on farm. The replacement of prophylactic antibiotics with safe, effective and reliable alternatives, therefore, remains a focus point.

Among candidate alternatives showing increasing promise are medium chain organic acids. These are unbranched and unsaturated monocarboxylic acids of caproic acid (C6:0, hexanoic acid), caprylic acid (C8:0, octanoic acid), capric acid (C10:0, decanoic acid) and lauric acid (C12:0, dodecanoic acid). Monoesters of free fatty acids are another type of single-chain lipid amphiphile, comprising esterified compounds consisting of one fatty acid molecule and one glycerol molecule. For example, monolaurin is the monoester formed from glycerol and lauric acid. The antimicrobial activity of medium chain organic acids (MCOA) has already been reviewed and described (Hanczakowska, 2017). The undissociated acid molecules penetrate the phospholipid bilayer membrane of bacteria and enter the cell where they dissociate due to the more alkaline $\mathrm{pH}$. The $\mathrm{pH}$ of the cell cytoplasm is lowered, which suppresses cytoplasmic enzymes and nutrient transport systems, leading to cell death. While some studies have shown stronger inhibitory effects with medium chain organic acid than with short or long chain organic acids (Hanczakowska et al., 2013; Hassinen et al., 1951; Nieman, 1954) and there are conflicting reports about the relative antimicrobial efficacy of the different medium chain acids. Only caprylic acid (C8:0), and, to a lesser extent, capric acid (C10:0) have shown significant antimicrobial activity against two strains of Escherichia coli in one study (Marounek et al., 2003). Other studies showed that both lauric acid (C12:0) and caprylic acid (C8:0) had the ability to damage the cytoplasmic structure of bacteria (Skrivanová et al., 2006). Lauric acid can disrupt Clostridium spp. cell membranes and cytoplasm (Shilling et al., 2013) whereas monolaurin has been shown to be more active against Gram-positive bacteria than the free fatty acid, lauric acid (Batovska et al., 2009). Previous in vitro studies (Neath et al., in press), confirm the efficacy of monolaurin against the Gram-positive bacteria, Staphylococcus aureus and Streptococcus suis. Caproic acid has efficacy against Gramnegative bacteria including Salmonella typhimurium and E. coli, as well as against Gram-positive bacteria. Different MCOA may, therefore, be expected to show differing efficacy in pigs, and it may successfully replace prophylactic zinc oxide, to reduce antibiotic or benzoic acid use, without any reduction in pig performance. To test this, two trials were carried out to evaluate the effects of MCOA on the growth performance of weaner/grower pigs in comparison with standard $\mathrm{ZnO}$ or benzoic acid.

\section{Materials and methods}

\section{Animals and trial design}

The studies were carried out in accordance with the U.K. Animals (Scientific Procedures) Act, 1986 and associated guidelines. Both trials used two hundred and forty (Large White $\times$ Landrace) $\times$ Danish Duroc pigs. Trial 1 pigs had an initial weight of $8.00 \pm 1.25 \mathrm{~kg}$ (mean \pm SD) at $28.4 \pm 0.69 \mathrm{~d}$ of age. Trial 2 pigs had an initial weight of $7.88 \pm 1.31 \mathrm{~kg}$ (mean \pm SD) at $27.8 \pm 0.52 \mathrm{~d}$ of age. Each trial consisted of 48 pens, each containing five mixed sex pigs. Start weight, sex and litter of origin were balanced across treatments within replicate. Pens within each replicate were randomly assigned to one of the six dietary treatments shown in Table 1 and 2. Pigs in Trial 1 remained on trial for $56 \mathrm{~d}$ after weaning (final weight $40.60 \pm 4.06 \mathrm{~kg}$ ); Trial 2 pigs remained on trial for $28 \mathrm{~d}$ after weaning (final weight $19.40 \pm 2.88 \mathrm{~kg}$ ). Feed and water were provided ad libitum throughout the experimental period.

\section{Dietary treatments}

A three-phase feeding programme was used: Diet 1 from weaning to d 14, diet 2 from d 15 to d 28 and diet 3 from d 29 to 56 . Day 0 to 28 was classed as the weaner period and d 29 to 56 the grower period. Diet formulations were provided by a UK commercial feed producer, according to a commercial 
Table 1. Dietary treatments used in Trial $1 .^{1}$

\begin{tabular}{|c|c|c|c|c|}
\hline Diet & Treatment & $\begin{array}{l}\text { Day 0-14 of trial } \\
\text { Weaner phase }\end{array}$ & $\begin{array}{l}\text { Day } 15-28 \text { of trial } \\
\text { Weaner phase }\end{array}$ & $\begin{array}{l}\text { Day } 29-56 \text { of trial } \\
\text { Grower phase }\end{array}$ \\
\hline $\begin{array}{l}1 \\
2 \\
3 \\
4 \\
5 \\
6\end{array}$ & $\begin{array}{l}\text { Control } \\
\mathrm{ZnO} \\
\mathrm{ZnO}+\mathrm{BA} \\
\mathrm{MCOA} \\
\mathrm{MCOA}+\mathrm{ZnO} \\
\mathrm{MCOA}+\mathrm{BA}\end{array}$ & $\begin{array}{l}\text { Basal diet } \\
\mathrm{ZnO} \\
\mathrm{ZnO}+\mathrm{BA} \\
\mathrm{MCOA} 1000 \mathrm{mg} / \mathrm{kg} \\
\mathrm{ZnO}+\mathrm{MCOA} 1000 \mathrm{mg} / \mathrm{kg} \\
\mathrm{BA}+\mathrm{MCOA} 1000 \mathrm{mg} / \mathrm{kg}\end{array}$ & $\begin{array}{l}\text { Basal diet } \\
\text { Basal diet } \\
\text { BA } \\
\text { MCOA } 1000 \mathrm{mg} / \mathrm{kg} \\
\text { MCOA } 1000 \mathrm{mg} / \mathrm{kg} \\
\text { BA + MCOA } 1000 \mathrm{mg} / \mathrm{kg}\end{array}$ & $\begin{array}{l}\text { Basal diet } \\
\text { Basal diet } \\
\text { BA } \\
\text { MCOA } 500 \mathrm{mg} / \mathrm{kg} \\
\text { MCOA } 500 \mathrm{mg} / \mathrm{kg} \\
\text { BA + MCOA } 500 \mathrm{mg} / \mathrm{kg}\end{array}$ \\
\hline
\end{tabular}

${ }^{1} \mathrm{BA}=$ benzoic acid at $5,000 \mathrm{mg} / \mathrm{kg}$ benzoic acid; $\mathrm{MCOA} 1000 \mathrm{mg} / \mathrm{kg}=2,000 \mathrm{mg} / \mathrm{kg}$ [medium chain organic acid/ silica blend] containing $1000 \mathrm{mg} / \mathrm{kg} \mathrm{MCOA}$ (C6:C8:C10:C12 1:1:1:1); MCOA $500 \mathrm{mg} / \mathrm{kg}=1000 \mathrm{mg} / \mathrm{kg}$ [medium chain organic acid/ silica blend] containing $500 \mathrm{mg} / \mathrm{kg} \mathrm{MCOA} \mathrm{(C6:C8:C10:C12} \mathrm{1:1:1:1).;} \mathrm{ZnO}$ = zinc oxide at $2,500 \mathrm{mg} / \mathrm{kg}$ zinc.

Table 2. Dietary treatments used in Trial $2 .^{1}$

$\begin{array}{llll}\text { Diet } & \text { Treatment } & \begin{array}{l}\text { Day } 0-14 \text { of trial } \\ \text { Weaner phase }\end{array} & \begin{array}{l}\text { Day 15-28 d of trial } \\ \text { Weaner phase }\end{array} \\ 1 & \text { Control } & \text { Basal diet } & \text { Basal diet } \\ 2 & \mathrm{ZnO} & \mathrm{ZnO} & \text { Basal diet } \\ 3 & \mathrm{MCOA} & \mathrm{MCOA} 1,500 \mathrm{mg} / \mathrm{kg} & \mathrm{MCOA} 1,500 \mathrm{mg} / \mathrm{kg} \\ 4 & \mathrm{MCOA} & \mathrm{MCOA} 750 \mathrm{mg} / \mathrm{kg} & \mathrm{MCOA} 750 \mathrm{mg} / \mathrm{kg} \\ 5 & \mathrm{C} 6 / \mathrm{C} 12 & \mathrm{C} 1,500 \mathrm{mg} / \mathrm{kg}+\mathrm{C} 121,500 \mathrm{mg} / \mathrm{kg} & \mathrm{C} 1,500 \mathrm{mg} / \mathrm{kg}+\mathrm{C} 121,500 \mathrm{mg} / \mathrm{kg} \\ 6 & \mathrm{C} 6 / \mathrm{C} 12 \mathrm{M} & \mathrm{C} 61,500 \mathrm{mg} / \mathrm{kg}+\mathrm{C} 12 \mathrm{M} 1,500 \mathrm{mg} / \mathrm{kg} & \mathrm{C} 61,500 \mathrm{mg} / \mathrm{kg}+\mathrm{C} 12 \mathrm{M} 1,500 \mathrm{mg} / \mathrm{kg}\end{array}$

${ }^{1}$ C6 1,500 mg/kg = 1,500 mg/kg C6:0 medium chain organic acid. C12 1,500 mg/kg =1,500 mg/kg C12:0 medium chain organic acid; C12M 1,500 mg/kg=1,500 $\mathrm{mg} / \mathrm{kg} \mathrm{C12}$ monolaurin (monoglycerides of lauric acid); MCOA 1,500 mg/kg =3,000 mg/kg [medium chain organic acid/ silica blend] containing 1,500 mg/kg MCOA (C6:C8:C10:C12 1:1:1:1); MCOA $750 \mathrm{mg} / \mathrm{kg}=1,500 \mathrm{mg} / \mathrm{kg}$ [medium chain organic acid/ silica additive blend] containing 750 mg/kg MCOA (C6:C8:C10:C12 1:1:1:1); $\mathrm{ZnO}=$ zinc oxide at $2,500 \mathrm{mg} / \mathrm{kg}$ zinc.

specification based on AHDB recommendations (Table 3). In Trial 1, the MCOA blend used consisted of a blend of C6:0, C8:0, C10:0 and C12:0 fatty acids (1:1:1:1) on a silica carrier (50\%). Feed-grade benzoic acid and $\mathrm{ZnO}$ were used. Trial 2 used the MCOA blend as in trial 1 in addition to a blend of purified C6:0 and C12:0 fatty acids and a blend of purified C6:0 fatty acid and $\mathrm{C} 12$ monolaurin. The additives were mixed into the commercial diets at the manufacturing stage and pelleted using a commercial pelleting process.

\section{Measurements and analytical methods}

Individual pig weights were recorded at start and on d 7, 14, 21, 28 (Trial 1 and 2), 35, 42, 49 and 56 (Trial 1). Feed troughs were emptied daily from weaning to $\mathrm{d} 21$ and then on d 28 (Trial 1 and 2), 35, 42, 49 and 56 (Trial 1) for the determination of pen feed intake. Average pen feed conversion ratio was calculated from body weight and pen feed intake measurements. Individual use of antibiotics, incidence of scour or other health problems and death were recorded. Faecal scores were evaluated by the same individual once daily at the same time each day from Monday to Friday for the duration of the $56 \mathrm{~d}$ trial, using the following scoring system: $1=$ firm, $2=$ soft, spreads slightly, 3 = very soft, spreads readily, 4 = watery, liquid consistency. Health scores were designated based on the proportion of pigs within a pen displaying signs of poor health, averaged over a particular period. For example, if a pen of five pigs had one pig that seemed unwell it would score $0.2(1 / 5)$.

\section{Statistical analysis}

Trial 1 and 2 data were analysed according to a randomised complete block design using the general linear model function of SPSS (version 21; IBM, Armonk, NY, USA) with the pen serving as the experimental unit. In trial 1 , data that violated that the assumptions of the GLM (normal distribution of residuals or homogeneity of variance) were reciprocally transformed prior to statistical analysis (d 0 to 7 feed conversion ratio (FCR), d 29 to 35 FCR and Diet 1 FCR). Significantly different means were separated using the Tukey's post-hoc test. Data are presented as leastsquare means along with the pooled SEM. Significance was recorded at $P<0.05$ and $P$-values of 0.05 to 0.1 were noted as trends. Separate two-treatment analyses were performed between control vs $\mathrm{ZnO}$, control vs MCOA/ benzoic acid (BA) and control vs MCOA. Faecal and health scores were analysed by Kruskal-Wallis using the nonparametric function of SPSS. Antibiotic usage was analysed by chi square analysis.

Trial 2 data were checked for normality of residuals using the Kolmogorov-Smirnov test and homogeneity of 
Table 3. Basal diet specifications. ${ }^{1}$

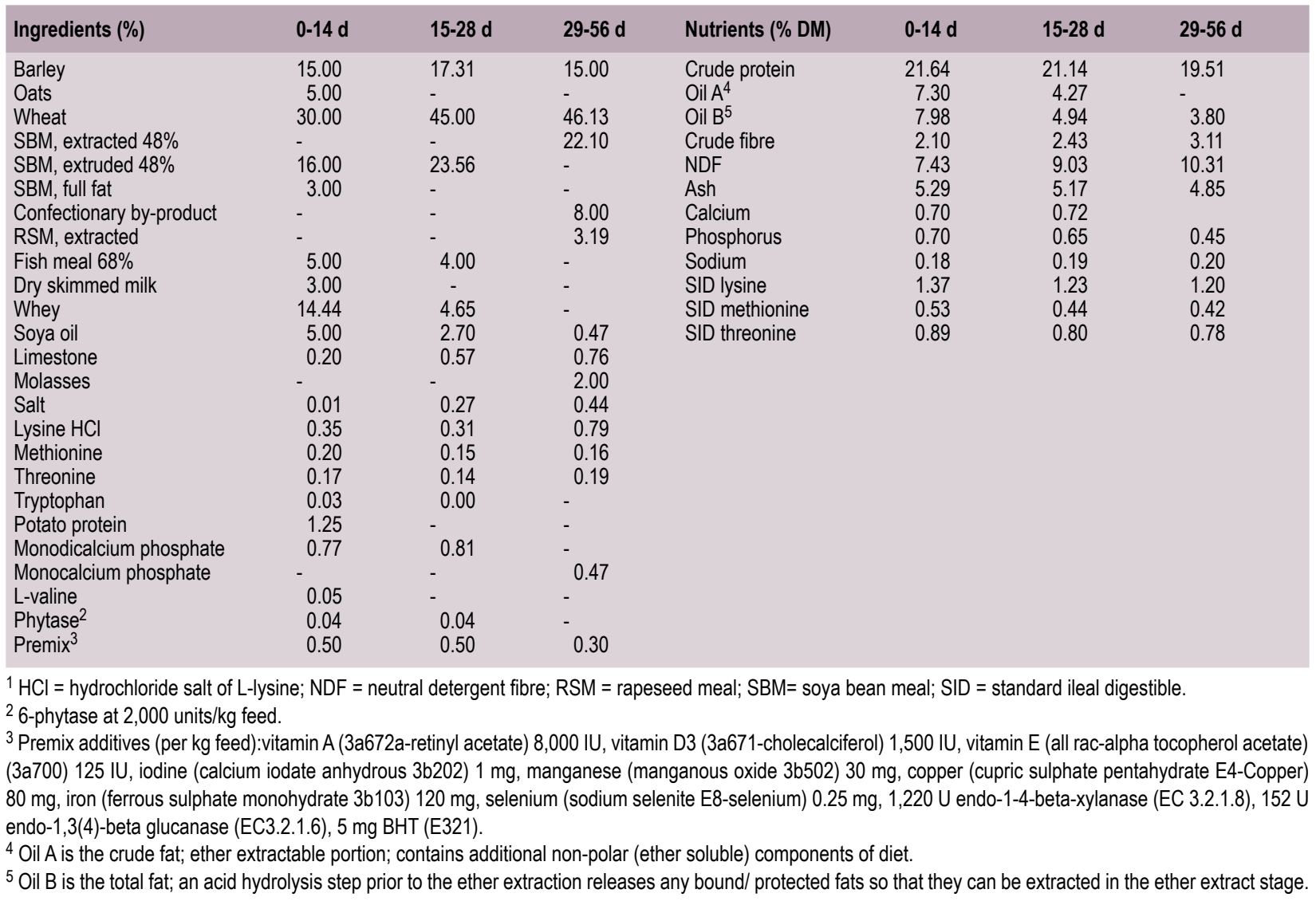

variance using the Levene's test prior to analysis. Diet 1 average daily feed intake (ADFI) data were heteroscedastic and therefore subject to a Kruskal-Wallis test analysis. Significantly different means were separated using the Tukey's post-hoc test. Data are presented as least-square means along with the pooled SEM. Significance was recorded at $P<0.05$ and $P$-values of 0.05 to 0.10 were noted as trends. Faecal and health scores were analysed by Kruskal-Wallis using the non-parametric function of SPSS. For both trials, incidence of death or pigs taken off trial were not analysed statistically due to insufficient numbers. Data were analysed in terms of pen weight at the start and weekly thereafter, pen ADFI each week, for each diet and overall, pen average daily liveweight gain (ADLG) each week, for each diet and overall, pen average FCR each week, for each diet and overall, overall health and faecal scores and antibiotic usage.

\section{Results}

\section{Trial 1}

Low initial growth rates reflected high antibiotic usage and the removal of the poorly performing pigs during the early stages of the study. Three pens were removed from the trial due to scouring and poor performance on d 7 (two from the MCOA + BA treatment and one from the $\mathrm{ZnO}+\mathrm{BA}$ treatment). As these pens were removed from the trial early in the study, the observations were removed from the data set prior to statistical analysis. A further 13 pigs were removed in the weaner phase due to scouring or other signs of ill health, with an additional four losses due to mortality from undetermined causes (three during the 0-28 $d$ phase and one in the 29-56 $d$ phase). A total of 77 pigs (32.1\%) required antibiotic treatment throughout the trial. There were notable (although nonsignificant) differences between treatment groups for piglets receiving antibiotics (Table 4), whereby eight pigs received antibiotics in the MCOA group compared to an average of 14 in all the other groups. For the remaining pigs, overall health $(0.14 \pm 0.153)$ and faecal $(2.16 \pm 0.059)$ scores were uniformly good throughout the trial, with no differences observed between the treatments.

The total feed intake of pigs was comparable between the dietary treatments throughout the study. In the grower period (29-56 d) pigs receiving MCOA + BA showed higher ADLG $(849 \mathrm{~g} / \mathrm{d})$ compared to pigs receiving the control $\operatorname{diet}(773 \mathrm{~g} / \mathrm{d})$ or those which had received $\mathrm{ZnO}$ in the two-week post-weaning period $(779 \mathrm{~g} / \mathrm{d} ; P=0.040)$. Pigs 
Medium chain organic acids in pig diets - 1

Table 4. Effect of replacing zinc oxide $(\mathrm{ZnO})$ and benzoic acid (BA) with medium chain organic acids on pig performance.,

\begin{tabular}{|c|c|c|c|c|c|c|c|c|}
\hline & Con & $\mathrm{ZnO}$ & $\mathrm{ZnO} / \mathrm{BA}$ & MCOA & MCOA/ZnO & MCOA/BA & SEM & $P$ \\
\hline \multicolumn{9}{|c|}{ Liveweight (kg) } \\
\hline d 0 & 7.97 & 7.95 & 8.00 & 7.93 & 7.93 & 7.94 & 0.032 & 0.492 \\
\hline d 14 & 10.39 & 10.75 & 10.71 & 10.18 & 10.62 & 10.79 & 0.398 & 0.774 \\
\hline $\mathrm{d} 28$ & 17.62 & 18.22 & 18.49 & 17.34 & 17.81 & 18.85 & 0.589 & 0.366 \\
\hline d 56 & 39.23 & 40.08 & 42.17 & 39.79 & 40.54 & 42.25 & 0.895 & 0.126 \\
\hline \multicolumn{9}{|l|}{$\operatorname{ADFI}(\mathrm{g} / \mathrm{d})^{3}$} \\
\hline $0-14 d$ & 213 & 215 & 199 & 196 & 200 & 229 & 19.0 & 0.759 \\
\hline $15-28 d$ & 700 & 678 & 677 & 654 & 641 & 680 & 41.5 & 0.877 \\
\hline $29-56 \mathrm{~d}$ & 1,221 & 1,250 & 1,318 & 1,241 & 1,305 & 1,287 & 30.2 & 0.163 \\
\hline Overall & 834 & 860 & 861 & 826 & 840 & 856 & 24.2 & 0.855 \\
\hline \multicolumn{9}{|c|}{ ADLG $(g / d)^{4}$} \\
\hline $0-14 \mathrm{~d}$ & 173 & 198 & 194 & 161 & 193 & 202 & 27.3 & 0.833 \\
\hline $15-28 d$ & 515 & 500 & 540 & 504 & 490 & 551 & 25.2 & 0.389 \\
\hline $29-56 d$ & $773^{a}$ & $779^{a}$ & $845^{a b}$ & $803^{a b}$ & $801^{a b}$ & $849^{b}$ & 19.2 & 0.040 \\
\hline Overall & 560 & 575 & 609 & 570 & 581 & 613 & 15.8 & 0.151 \\
\hline \multicolumn{9}{|c|}{ ADLG using individual pig } \\
\hline $\begin{array}{l}\text { as experil } \\
\text { Overall }\end{array}$ & $559^{a}$ & $576^{\mathrm{ab}}$ & $605^{a b}$ & $569^{a b}$ & $580^{\mathrm{ab}}$ & $631^{b}$ & 16.6 & 0.044 \\
\hline \multicolumn{9}{|l|}{$\mathrm{FCR}^{5}$} \\
\hline $0-14 d$ & 1.17 & 1.08 & 1.10 & 1.26 & 1.04 & 1.06 & 0.062 & 0.158 \\
\hline $15-28 d$ & 1.36 & 1.35 & 1.26 & 1.30 & 1.32 & 1.24 & 0.054 & 0.623 \\
\hline $29-56 d$ & 1.58 & 1.60 & 1.55 & 1.55 & 1.63 & 1.52 & 0.025 & 0.071 \\
\hline Overall & 1.50 & 1.46 & 1.41 & 1.45 & 1.44 & 1.39 & 0.025 & 0.065 \\
\hline Antibiotics $^{6}$ & 14 & 12 & 14 & 8 & 12 & 17 & & \\
\hline Off trial & 1 & 4 & 7 & 1 & 4 & 11 & & \\
\hline Dead & 0 & 1 & 1 & 0 & 0 & 2 & & \\
\hline
\end{tabular}

${ }^{1} \mathrm{Con}=$ control; $\mathrm{MCOA}=$ medium chain organic acids (C6:C8:C10:C12 1:1:1:1) at $1000 \mathrm{mg} / \mathrm{kg}$ day 0-28 and $500 \mathrm{mg} / \mathrm{kg}$ day $29-56$ of trial; $\mathrm{MCOA} / \mathrm{ZnO}=\mathrm{ZnO}$ at 2,500 $\mathrm{mg} / \mathrm{kg}$ day 0-14 of trial, MCOA (C6:C8:C10:C12 1:1:1:1) at $1000 \mathrm{mg} / \mathrm{kg}$ day $0-28$ and $500 \mathrm{mg} / \mathrm{kg}$ day 29-56 of trial; MCOA/BA = MCOA (C6:C8:C10:C12 1:1:1:1) at $1000 \mathrm{mg} / \mathrm{kg} \mathrm{d} 0-28$ and $500 \mathrm{mg} / \mathrm{kg} \mathrm{d} 29-56$ of trial, benzoic acid at 5,000 mg/kg throughout trial; $\mathrm{ZnO}=\mathrm{ZnO}$ at 2,500 mg/kg day 0-14 of trial; $\mathrm{ZnO} / \mathrm{BA}=\mathrm{ZnO}$ at 2,500 $\mathrm{mg} / \mathrm{kg}$ zinc day $0-14$ of trial, benzoic acid at $5,000 \mathrm{mg} / \mathrm{kg}$ throughout trial.

2 Data given are means of each treatment. Con, $\mathrm{ZnO}, \mathrm{ZnO} / \mathrm{BA}, \mathrm{MCOA}, 8 \times 5$ pigs per treatment; $\mathrm{MCOA} / \mathrm{ZnO} 7 \times 5$ pigs; $\mathrm{MCOA} / \mathrm{BA} 6 \times 5$ pigs. Means within row that do not share a common superscript differ significantly $(P<0.05)$.

${ }^{3}$ Least square means of average daily feed intake.

${ }^{4}$ Least square means of average daily liveweight gain.

${ }^{5}$ Least square means of FCR.

${ }^{6}$ No. of pigs requiring antibiotic treatment; standard treatment of amoxycillin $15 \mathrm{mg} / \mathrm{kg} /$ day for $5 \mathrm{~d}$. Specific two-treatment comparisons Con vs MCOA/ BA: ADLG $29-56 \mathrm{~d} P=0.07,0-56 \mathrm{~d} P=0.086$, FCR 0-56 d; $P=0.008$.

receiving MCOA showed an intermediate growth rate between the control and the MCOA + BA treatment in this period $(803 \mathrm{~g} / \mathrm{d})$. When individual pig growth data were analysed, the difference between the MCOA + BA and the control group reached significance for the overall trial period $(631 \mathrm{~g} / \mathrm{d}$ vs $559 \mathrm{~g} / \mathrm{d} ; P=0.044)$. Differences were most pronounced in the period $43-49 \mathrm{~d}$, where pigs receiving $\mathrm{MCOA}+\mathrm{BA}$ gained $922 \mathrm{~g} / \mathrm{d}$ compared to 765 $\mathrm{g} / \mathrm{d}$ for pigs receiving $\mathrm{ZnO}(P=0.002)$. Consequently, pigs receiving $\mathrm{MCOA}+\mathrm{BA}$ ended the trial $3.02 \mathrm{~kg}$ heavier than control pigs. There was a tendency for treatment to influence FCR $(P=0.065)$ throughout the $56 \mathrm{~d}$ trial; two-way treatment comparisons showed the difference between the control pigs and the MCOA + BA treated pigs was highly significant $(P=0.008)$ whereas neither $\mathrm{ZnO}$ or MCOA as treatments significantly influenced FCR. Pigs receiving $\mathrm{ZnO}$ did not show any increased ADLG compared to control pigs. However, when $\mathrm{ZnO}$ was removed from the diet after $14 \mathrm{~d}$, there was a reduction in performance (Table 5) which appeared to be mitigated by the addition of benzoic acid ( 485 vs $383 \mathrm{~g} / \mathrm{d}$; $P=0.039$ ).
Trial 2

Pigs were in good health throughout the study with overall health scores of $0.04 \pm 0.09$ ), irrespective of dietary treatment. Antibiotic treatment was relatively low at $12.9 \%$, whereby eight pigs were removed from the trial and there were no mortalities. Mean faecal consistency scores were good (mean $2.23 \pm 0.16$; soft) throughout and there was little incidence of post-weaning diarrhoea. Piglets fed the diets containing $\mathrm{ZnO}$ had firmer faecal material than those fed the $750 \mathrm{mg} /$ $\mathrm{kg}$ MCOA or the C6/C12M treatment $(P<0.05)$. Growth performance data are presented in Table 6 . Pigs receiving $750 \mathrm{mg} / \mathrm{kg}$ MCOA had the lowest feed intakes, which was reflected in growth rate as these pigs grew more slowly than those receiving $\mathrm{ZnO}$ or the $\mathrm{C} 6 / \mathrm{C} 12 \mathrm{M}(P<0.05)$ until $21 \mathrm{~d}$ after weaning. At $21 \mathrm{~d}$, pigs fed the $\mathrm{ZnO}$ were the heaviest and grew the fastest up until day 21 , but, by $\mathrm{d} 28$, there were no significant differences in growth rate or liveweight between the treatment groups. During the first feeding phase the pigs receiving $\mathrm{ZnO}$ showed the best FCR, whereas, in the second phase, this effect was no longer seen. Both C6/ $\mathrm{C} 12$ and $\mathrm{C6} / \mathrm{C} 12 \mathrm{M}$ treatments appeared to improve FCR during the second period ( $\mathrm{d} 15-28)$, for $\mathrm{C} 6 / \mathrm{C} 12 \mathrm{M}(P<0.01)$. 
Table 5. Trial 1: Effect of replacing zinc oxide ( $\mathrm{ZnO})$ and benzoic acid (BA) with medium chain organic acids on ADLG weekly average (g/day)., ${ }^{1,2}$

$\begin{array}{lllllllll} & \text { Con } & \text { ZnO } & \text { ZnO/BA } & \text { MCOA } & \text { MCOA/ZnO } & \text { MCOA/BA } & \text { S.E.M } & P \\ \text { 0-7 d } & 48 & 75 & 37 & 40 & 49 & 75 & 18.7 & 0.571 \\ \text { 8-14 d } & 298 & 325 & 352 & 281 & 334 & 325 & 34.9 & 0.736 \\ \text { 15-21 d } & 465^{\mathrm{ab}} & 363^{\mathrm{a}} & 485^{\mathrm{b}} & 409^{\mathrm{ab}} & 411^{\mathrm{ab}} & 443^{\mathrm{ab}} & 27.5 & 0.039 \\ 21-28 \mathrm{~d} & 568 & 603 & 577 & 585 & 555 & 630 & 31.3 & 0.654 \\ \text { 29-35d } & 751 & 716 & 771 & 708 & 714 & 764 & 38.4 & 0.755 \\ 36-42 \mathrm{~d} & 689 & 703 & 768 & 698 & 720 & 692 & 29.9 & 0.471 \\ \text { 43-49 d } & 770^{\mathrm{a}} & 765^{\mathrm{a}} & 866^{\mathrm{ab}} & 865^{\mathrm{ab}} & 853^{\mathrm{ab}} & 922^{\mathrm{b}} & 27.0 & 0.002 \\ 50-56 \mathrm{~d} & 879 & 941 & 981 & 940 & 920 & 986 & 33.8 & 0.265\end{array}$

${ }^{1} \mathrm{Con}=$ control; $\mathrm{MCOA}=$ medium chain organic acids (C6:C8:C10:C12 1:1:1:1) at $1000 \mathrm{mg} / \mathrm{kg}$ day 0-28 and $500 \mathrm{mg} / \mathrm{kg}$ day $29-56$ of trial; $\mathrm{MCOA} / \mathrm{ZnO}=\mathrm{ZnO}$ at 2,500 $\mathrm{mg} / \mathrm{kg}$ day 0-14 of trial, MCOA (C6:C8:C10:C12 1:1:1:1) at $1000 \mathrm{mg} / \mathrm{kg}$ day 0-28 and $500 \mathrm{mg} / \mathrm{kg}$ day 29-56 of trial; MCOA/BA = MCOA (C6:C8:C10:C12 1:1:1:1) at $1000 \mathrm{mg} / \mathrm{kg} \mathrm{d} 0-28$ and $500 \mathrm{mg} / \mathrm{kg} \mathrm{d} 29-56$ of trial, benzoic acid at 5,000 mg/kg throughout trial; $\mathrm{ZnO}=\mathrm{ZnO}$ at 2,500 mg/kg day 0-14 of trial; $\mathrm{ZnO} / \mathrm{BA}=\mathrm{ZnO}$ at 2,500 $\mathrm{mg} / \mathrm{kg}$ zinc day $0-14$ of trial, benzoic acid at $5,000 \mathrm{mg} / \mathrm{kg}$ throughout trial.

2 Data given are means of each treatment. Con, $\mathrm{ZnO}, \mathrm{ZnO} / \mathrm{BA}, \mathrm{MCOA}, 8 \times 5$ pigs per treatment; $\mathrm{MCOA} / \mathrm{ZnO} 7 \times 5$ pigs; MCOA/ BA $6 \times 5$ pigs. Means within row that do not share a common superscript differ significantly $(P<0.05)$

\section{Discussion}

In trial 1, the below-average growth rates and above-average antibiotic use throughout the weaner phase indicated a sub-clinical disease challenge. The reduction of antibiotic intervention in animals receiving MCOA compared to all other groups, although non-significant, was noteworthy. The positive health effect may be explained by a direct antimicrobial effect of MCOA and supports earlier findings that a blend of C6:0, C8:0 and C10:0 reduced the coliform count in the colon (Yen et al., 2015). The absence of a notable effect of MCOA on growth performance in this experiment may have been partly compounded by the removal of poorly performing animals from the other treatment groups. These results did not agree with those of Hanczakowska et al. (2011), who demonstrated that piglets receiving C8:0, $\mathrm{C} 10: 0$, or a blend of these fed at $0.2 \%$ from 7-84 $\mathrm{d}$ of age showed improved growth performance (ADLG, FCR $P<0.05$ ) compared to control-fed animals. The magnitude of response was likely influenced by the type or chain length of medium chain acid (C6:0, C8:0, C10:0 and C12:0), inclusion level, and background pathogen challenge, although there are too few published studies to confirm this. The lack of growth improvement in response to $\mathrm{ZnO}$ in this

Table 6. Trial 2: Effect of replacing zinc oxide $(\mathrm{ZnO})$ with different types and levels of medium chain organic acids on weaning pig performance. ${ }^{1}$

\begin{tabular}{|c|c|c|c|c|c|c|c|c|}
\hline & Con & $\mathrm{ZnO}$ & $\mathrm{MCOA}_{1500}$ & $\mathrm{MCOA}_{750}$ & $\mathrm{C} 6 / \mathrm{C} 12$ & $\mathrm{C} 6 / \mathrm{C} 12 \mathrm{M}$ & S.E.M & $P$ \\
\hline \multicolumn{9}{|l|}{ Liveweight (kg) } \\
\hline d 0 & 7.79 & 7.89 & 7.82 & 7.82 & 7.89 & 7.87 & 0.031 & 0.161 \\
\hline d 14 & $11.66^{\mathrm{ab}}$ & $12.17^{a}$ & $11.24^{\mathrm{ab}}$ & $10.66^{b}$ & $11.24^{\mathrm{ab}}$ & $11.19^{\mathrm{ab}}$ & 0.255 & $<0.010$ \\
\hline d 21 & $14.56^{\mathrm{ab}}$ & $15.33^{\mathrm{a}}$ & $14.71^{\mathrm{ab}}$ & $13.72^{b}$ & $14.61^{\mathrm{ab}}$ & $15.01^{a}$ & 0.336 & $<0.050$ \\
\hline \multirow{2}{*}{\multicolumn{9}{|c|}{$\operatorname{ADFI}(g / d)^{2}$}} \\
\hline & & & & & & & & \\
\hline $0-14 \mathrm{~d}$ & $291^{a b}$ & $306^{a}$ & $278^{a b}$ & $239^{b}$ & $258^{a b}$ & $256^{\mathrm{ab}}$ & 13.9 & $<0.050$ \\
\hline $15-28 d$ & 729 & 736 & 738 & 659 & 715 & 717 & 30.7 & 0.469 \\
\hline Overall & 511 & 521 & 505 & 448 & 486 & 484 & 20.7 & 0.171 \\
\hline \multicolumn{9}{|l|}{$\operatorname{ADLG}(\mathrm{g} / \mathrm{d})^{3}$} \\
\hline $0-14 \mathrm{~d}$ & $276^{a b}$ & $308^{a}$ & $244^{a b}$ & $203^{b}$ & $239^{a b}$ & $237^{a b}$ & 18.2 & $<0.010$ \\
\hline $15-28 d$ & 543 & 556 & 568 & 539 & 586 & 597 & 26.0 & 0.564 \\
\hline Overall & 409 & 433 & 408 & 371 & 413 & 413 & 17.0 & 0.242 \\
\hline \multicolumn{9}{|l|}{$\mathrm{FCR}^{4}$} \\
\hline $0-14 d$ & $1.07^{a b}$ & $1.01^{\mathrm{a}}$ & $1.16^{a b}$ & $1.20^{\mathrm{b}}$ & $1.11^{\mathrm{ab}}$ & $1.09 \mathrm{ab}$ & 0.037 & $<0.010$ \\
\hline $15-28 d$ & $1.36^{\mathrm{a}}$ & $1.32^{\mathrm{ab}}$ & $1.32^{\mathrm{ab}}$ & $1.21^{\mathrm{b}}$ & $1.22^{\mathrm{ab}}$ & $1.21^{\mathrm{b}}$ & 0.034 & $<0.010$ \\
\hline Overall & 1.25 & 1.20 & 1.24 & 1.20 & 1.18 & 1.17 & 0.021 & 0.058 \\
\hline Antibiotics ${ }^{5}$ & 0 & 4 & 5 & 3 & 9 & 10 & & \\
\hline Off-trial & 0 & 0 & 1 & 1 & 1 & 5 & & \\
\hline Dead & 0 & 0 & 0 & 0 & 0 & 0 & & \\
\hline
\end{tabular}

${ }^{1}$ Data given are means of each treatment. $8 \times 5$ pig per treatment. Means within row that do not share a common superscript differ significantly $(P<0.05)$.

${ }^{2}$ Least square means of average daily feed intake.

${ }^{3}$ Least square means of average daily liveweight gain.

${ }^{4}$ Least square means of feed conversion ratio.

${ }^{5} \mathrm{No}$. of pigs requiring antibiotic treatment; standard treatment of amoxycillin $15 \mathrm{mg} / \mathrm{kg} /$ day for $5 \mathrm{~d}$. 
study was noteworthy in view of the ongoing widespread use of this medication. When $\mathrm{ZnO}$ was removed from the diet after $14 \mathrm{~d}$, in line with standard practice and regulatory requirements, there was an immediate reduction in growth rate; whereby pigs grew $102 \mathrm{~g} / \mathrm{d}$ less than control pigs (d 15-21; Table 5). Performance reductions in response to $\mathrm{ZnO}$ withdrawal has previously been reported (PortocareroKhan and Jurado-Candaliga, 2006) and the current results suggested that the short-term benefits of this medication may be negated by post-withdrawal performance reduction.

In contrast to the lack of growth response seen when MCOA or $\mathrm{ZnO}$ were used individually, the $13 \%$ increase in growth rate (compared to control animals) observed when benzoic acid was used in addition to MCOA was highly notable. The difference between these pigs and the pigs receiving $\mathrm{BA}$ plus $\mathrm{ZnO}$ appeared to confirm that the combination, not solely $\mathrm{BA}$, was responsible for the large increase. Benzoic acid in combination with $\mathrm{ZnO}$ (which is widely practised in the U.K.) resulted in an $8 \%$ increase in ADLG. When $\mathrm{ZnO}$ was omitted from the diet, and BA was instead used in combination with MCOA, the increase in ADLG reached 13\%, and there was a 7\% improvement in FCR. This is the first published study that reported a combination of BA and MCOA could have a complementary effect, which deserves further investigation.

Pigs in the second weaner study had fewer health problems and overall better performance than those in the first trial, and treatment effects on health were less pronounced. Addition of $\mathrm{ZnO}$ tended to have a positive impact on average daily liveweight gain in the first two weeks post-weaning while the effects of the MCOA were less pronounced. In this trial, combinations of $\mathrm{C} 6$ and $\mathrm{C} 12$ or $\mathrm{C} 6$ and $\mathrm{C} 12 \mathrm{M}$ were chosen based on previous in vitro experiments (Neath et al., in press) which showed efficacy of C6 against the Gram-negative microorganisms S. typhimurium and $E$. coli, and efficacy of C12M against the Gram-positive microorganisms S. suis and S. aureus. Although both C6/ $\mathrm{C} 12$ and $\mathrm{C6} / \mathrm{C} 12 \mathrm{M}$ treatments appeared to improve FCR during the second period, overall, the MCOA did not match the growth response seen with $\mathrm{ZnO}$. Possibly, the inclusion levels of the individual MCOA were too low to be effective. Given the inconsistency of the response to $\mathrm{ZnO}$ (in the first study, pigs receiving $\mathrm{ZnO}$ showed little measurable improvement in growth performance compared to control pigs, while in the second study the effect of $\mathrm{ZnO}$ was more pronounced) it could not be concluded whether MCOA could fully replace $\mathrm{ZnO}$. The results suggested that this may depend on the background pathogen challenge. The type of MCOA and the inclusion level appeared to play a role in the growth performance response and requires further attention.

\section{Conclusions}

A blend of MCOA in combination with BA resulted in improved growth performance in pigs from weaning up to $40 \mathrm{~kg}$, compared to a control group. Type of MCOA (chain length and monoester) influenced the response in weaner diets. Further studies would be useful to explore and refine the use of MCOA in combination with $\mathrm{BA}$, as a strategy to further reduce antibiotic use in the pig sector.

\section{Conflict of interest}

The author declare no conflict of interest.

\section{References}

Agriculture and Horticulture Development Board (AHDB), 2019. Antibiotic usage data in pigs. Agriculture and horticulture development board e-medicines book. Available at: https://eMBPigs.ahdb.org.uk/.

Batovska, D.I., Todorova, I.T., Tsvetkova, I.V. and Najdenski, H.M., 2009. Antibacterial study of the medium chain fatty acids and their 1-monoglycerides: individual effects and synergistic relationship. Polish Journal of Microbiology 58: 43-47.

Driver, A., 2017. The future of zinc oxide - an evidence-based decision or a political stitch-up? Pig World. March 3, 2017. Available at: https://tinyurl.com/2p8t5ndv

European Commission, 2019. Regulation (EU) 2019/4 of the European Parliament and of the Council of 11 December 2018 on the manufacture, placing on the market and use of medicated feed, amending Regulation (EC) No 183/2005 of the European Parliament and of the Council and repealing Council Directive 90/167/EEC. Official Journal of the European Union 62 L4: 1-24. Available at: https://eur-lex.europa.eu/legal-content/EN/ TXT/?uri=OJ:L:2019:004:TOC

Hanczakowska, E., 2017. The use of medium-chain fatty acids in piglet feeding - a review. Annals of Animal Science 17(4): 967-977. https://doi.org/10.1515/aoas-2016-0099

Hanczakowska, E., Szewczyk, A. and Okoń, K., 2011. Effects of dietary caprylic and capric acids on piglet performance and mucosal epithelium structure of the ileum. Journal of Animal and Feed Sciences 20: 545-554. https://doi.org/10.22358/jafs/66213/2011

Hanczakowska, E., Szewczyk, A., Świątkiewicz, M. and Okoń, K., 2013. Short and medium-chain fatty acids as a feed supplement for weaning and nursery pigs. Polish Journal of Veterinary Sciences 16: 647-654. https://doi.org/10.2478/pjvs-2013-0092

Hassinen, J.B., Durbin, G.T. and Bernhart, F.W., 1951. The bacteriostatic effects of saturated fatty acids. Archives of Biochemistry and Biophysics 31: 183-189. https://doi.org/10.1016/00039861(51)90204-4

Hojberg, O., Canibe, N., Poulsen, H.D., Hedemann, M.S. and Jensen, B.B., 2005. Influence of dietary zinc oxide and copper sulfate on the gastrointestinal ecosystem in newly weaned piglets. Applied Environmental Microbiology 71(5): 2267-2277. https://doi. org/10.1128/AEM.71.5.2267-2277.2005 


\section{N. Portocarero}

Lekagul, A., Tangcharoensathien, V. and Yeunga, S., 2019. Patterns of antibiotic use in global pig production: a systematic review. Veterinary and Animal Science 7: 100058. https://doi.org/10.1016/j. vas.2019.100058

Marounek, M., Skrivanová, E. and Rada, V., 2003. Susceptibility of Escherichia coli to C2-C18 fatty acids. Folia Microbiologica 48: 731-735. https://doi.org/0.1007/BF02931506

Neath, C., Portocarero, N. and Jones, C., in press. In vitro susceptibility of swine pathogens to feed additives and active ingredients with potential as antibiotic replacements. Journal of Applied Microbiology. https://doi.org/10.1111/jam.15318

Nieman, C., 1954. Influence of trace amounts of fatty acids on the growth of microorganisms. Bacteriological Reviews 18: 147-163. https://doi.org/10.1128/br.18.2.147-163.1954

Portocarero-Khan, N. and Jurado-Candaglia, S., 2006. Desde la madra hasta el final del cebo con Formi. Albéitar 94: 76-77.

Shilling, M., Matt, L., Rubin, E., Visitacion, M.P., Haller, N.A., Grey, S.F. and Woolverton, C.J., 2013. Antimicrobial effects of virgin coconut oil and its medium-chain fatty acids on Clostridium difficile. Journal of Medicinal Food 16: 1079-1085. https://doi.org/10.1089/ jmf.2012.0303
Skrivanová, E., Marounek, M., Benda, V. and Brezina, P., 2006. Susceptibility of Escherichia coli, Salmonella sp. and Clostridium perfringens to organic acids and monolaurin. Veterinarni Medicina 51: 81-88. https://doi.org/10.17221/5524-VETMED

Srivastava, R.C., Farookh, A., Ahmad, N., Misra, M., Hasan, S.K. and Husain, M.M., 1995. Reduction of cisplatin induced nephrotoxicity by zinc histidine complex: the possible implication of nitric oxide. Biochemistry and Molecular Biology International 36: 855-862.

Starke, I.C., Pieper, R., Neumann, K., Zentek, J. and Vjen, W., 2014. The impact of high dietary zinc oxide on the development of the intestinal microbiota in weaned piglets. FEMS Microbiology Ecology 87(2): 416-427. https://doi.org/10.1111/1574-6941.12233

Vahjen, W., Pieper, R. and Zentek, J., 2011. Increased dietary zinc oxide changes the bacterial core and enterobacterial composition in the ileum of piglets. Journal of Animal Science 89(8): 2430-2439. https://doi.org/10.2527/jas.2010-3270

Veterinary Medicines Directorate, 2016. Understanding the population correction unit used to calculate antibiotic use in food producing animals. Available at: https://tinyurl.com/yckneh8v

Yen, H.-C., Lai, W.-K., Lin, C.-S. and Chiang, S.-H., 2015. Mediumchain triglyceride as an alternative of in-feed colistin sulfate to improve growth performance and intestinal microbial environment in newly weaned pigs. Animal Science Journal 86: 99-104. https:// doi.org/10.1111/asj.12248 